\title{
Pengaruh Metode Praktikum terhadap Hasil Belajar IPA Konsep Struktur Bagian Tumbuhan pada Murid Kelas IV SDN No. 166 Inpres Bontorita Kecamatan Polongbangkeng Utara Kabupaten Takalar
}

\author{
Irmawanty. \\ Pendidikan Guru Sekolah Dasar, Fakultas Keguruan dan Ilmu Pendidikan \\ Universitas Muhammadiyah Makassar \\ Iqramsyar34@gmail.com
}

\begin{abstract}
ABSTRAK
Penelitian ini adalah penelitian Eksperimen (Pre-Eksperimental) dengan desain OneGroup Pretest-Posttest Design yang bertujuan untuk mengetahui Pengaruh Metode Praktikum terhadap Hasil Belajar IPA Konsep Struktur Bagian Tumbuhan pada Siswa Kelas IV SDN No. 166 Inpres Bontorita Kecamatan Polongbangkeng Utara Kabupaten Takalar. Variabel bebas dalam penelitian ini adalah Metode Praktikum dalam pembelajaran Ilmu Pengetahuan Alam dan variabel terikat adalah hasil belajar Ilmu Pengetahuan Alam murid kelas IV SDN No. 166 Inpres Bontorita Kecamatan Polongbangkeng Utara Kabupaten Takalar. Populasi penelitian ini adalah seluruh siswa SDN No. 166 Inpres Bontorita. Sampel penelitian adalah siswa kelas IV SDN No. 166 Inpres Bontorita yang berjumlah 20 orang. Data hasil penelitian diperoleh dengan memberikan pretest pada awal pertemuan dan posttest pada akhir pertemuan berbentuk soal uraian yang dianalisis menggunakan uji t. Berdasarkan hasil analisis disimpulkan bahwa terdapat perbedaan hasil belajar siswa dengan menerapkan metode praktikum pada materi konsep struktur bagian tumbuhan. Hal ini dibuktikan dengan hasil analisis statistika deskriptif menunjukkan bahwa rata-rata nilai hasil belajar IPA pada pretest 57,00 dengan standard deviasi 18,382 sedangkan rata-rata hasil belajar IPA pada posttest 90,00 dengan standard deviasi 10,260. Sedangkan hasil analisis statistik inferensial a=0,05 diperoleh $t_{\text {hitung }}>t_{\text {table }}=7,183>3,88$. Perbedaan antara hasil pretest dan posttest signifikan dan dapat disimpulkan bahwa $\mathrm{H}_{0}$ ditolak dan $\mathrm{H}_{1}$ diterima.
\end{abstract}

Kata kunci : Metode Praktikum; Hasil Belajar 


\section{PENDAHULUAN}

Pendidikan dasar merupakan jenjang pendidikan yang melandasi jenjang pendidikan menengah setiap warga Negara yang berusia tujuh sampai dengan lima belas tahun wajib mengikuti pendidikan dasar. Pemerintah dan pemerintah daerah menjamin terselenggaranya wajib belajar bagi setiap warga Negara yang berusia enam tahun pada jenjang pendidikan dasar tanpa memungut biaya (Hafid,Dkk,2014:83).

IPA merupakan ilmu yang pada awalnya diperoleh dan dikembangkan berdasarkan percobaan (induktif) namun pada perkembangan selanjutnya IPA juga diperolrh dan dikembangkan berdasarkan teori (deduktif) (Eka Sulistyowati, 2014:22). IPA adalah usaha manusia dalam memahami alam semesta melalui pengamatan yang tepat pada sasaran, serta menggunakan prosedur, dan dijelaskan dengan penalaran sehingga mendapatkan suatu kesimpulan (Susanto,2013:1167).

Pembelajaran SAINS di sekolah dasar dikenal dengan pembelajaran Ilmu Pengetahuan Alam (IPA). Konsep IPA di sekolah dasar merupakan konsep yang masih terpadu karena belum dipisahkan tersendiri, seperti mata pelajaran Biologi, Kimia, dan Fisika.

Pembelajaran IPA di sekolah dasar dalam BSNP tahun 2006 dimaksudkan untuk memperoleh keyakinan terhadap Tuhan Yang Maha Esa, mengembangkan pemahaman konsep IPA, mengembangkan rasa ingin tahu, mengembangkan keterampilan proses, meningkatkan kesadaran, dan memperoleh bekal pengetahuan (Susanto,2013:171).

Dalam GBHN (1993:119) pendidikan dasar sebagai jenjang awal dari pendidikan di sekolah lebih ditingkatkan pemerataan, kualitas, dan pengembangannya agar dapat memberikan dasar pembentukan pribadi manusia sebagai warga masyarakat dan warga Negara yang berbudi pekerti luhur, beriman dan bertakwa kepada Tuhan Yang Maha Esa, serta berkemampuan serta berketerampilan dasar sebagai bekal untuk pendidikan selanjutnya atau bekal hidup dalam masyarakat. Dinyatakan bahwa kualitas pendidikan perlu disesuaikan dengan kemajuan ilmu pengetahuan dan tekhnologi serta tuntutan perkembangan pembangunan. Khusus IPA tidak hanya untuk memahami pengetahuan tentang fakta-fakta, konsep-konsep dan pengertian IPA saja, melainkan juga untuk mengembangkan keterampilan dan sikapsikap yang diperlukan untuk mencapai pengetahuan itu. Oleh karena itu, pembelajaran 
IPA di sekolah dasar kegiatan seperti pengamatan, penyelidikan, penyusunan, dan pengujian gagasan dalam membangun pengetahuan sangat diutamakan.

Konsep materi Struktur Bagian Tumbuhan salah satu topik yang harus diajarkan kepada murid kelas IV. Konsep tersebut dalam pembelajarannya dianjurkan agar murid melakukan praktik untuk mengetahui struktur bagian tumbuhan serta dapat memanfaatkannya dalam kehidupan sehari-hari.

Berdasarkan uraian diatas, maka perlu dilakukan penelitian mengenai penerapan Metode Praktikum. Metode praktikum diharapkan dapat meningkatkan hasil belajar murid pada konsep struktur bagian tumbuhan di kelas IV SDN Inpres Bontorita, kabupaten Takalar.

Berdasarkan uraian di atas rumusan masalah dalam penelitian ini adalah: "Bagaimana pengaruh metode praktikum terhadap hasil belajar murid konsep struktur bagian tumbuhan?". Tujuan penelitian ini adalah adalah untuk mengetahui pengaruh metode praktikum terhadap hasil belajar murid konsep struktur bagian tumbuhan.

\section{Belajar}

Menurut R.Gagne (Susanto,2013:1) belajar dapat didefinisikan sebagai suatu proses dimana suatu organisme berubah perilakunya sebagai akibat pengalaman. Bagi Gagne, belajar dimaknai sebagai suatu proses untuk memperoleh motivasi dalam pengetahuan, keterampilan, kebiasaan, dan tingkah laku. Selain itu, Gagne juga menekankan bahwa belajar sebagai suatu upaya memperoleh pengetahuan atau keterampilan melalui instruksi.

Menurut Hamalik (Susanto,2013:3-4) belajar adalah memodifikasi atau memperteguh perilaku melalui pengalaman (learning is defined as the modificator or strengthening of behavior through experiencing). Menurut pengertian ini, belajar merupakan suatu proses, suatu kegiatan, dan bukan merupakan suatu hasil atau tujuan. Hamalik juga menegaskan bahwa belajar adalah suatu proses perubahan tingkah laku individu atau seseorang melalui interaksi dengan lingkungannya.

Adapun pengertian belajar menurut Nasution (Uno, 2011:141) bahwa belajar adalah aktivitas yang menghasilkan perubahan pada diri individu yang belajar, baik aktual maupun potensial. Perubahan itu pada dasarnya didapatkannya berupa kemungkinan baru, yang berlaku dalam waktu yang relatif lama. 
Beberapa pengetian belajar yang telah dikemukakan diatas, terdapat beberpa perumusan yang berbeda satu dengan yang lainnya bergantung dari ahli yang mengemukakannya. Dari beberapa pengertian belajar diatas, dapat diartikan bahwa belajar pada dasarnya adalah suatu proses aktivitas mental seseorang dalam berinteraksi dengan lingkungannya sehingga menghasilkan perubahan tingkah laku yang bersifat positif baik perubahan dalam aspek pengetahuan, sikap, maupun psikomotor (Wina Sanjaya, 2008:229).

Hasil belajar adalah perubahan-perubahan yang dapat terjadi pada diri murid, baik yang menyangkut aspek kognitif, afektif, dan psikomotor sebagai hasil dari kegiatan belajar. Gagne dalam Dahar (2011:118) mengemukakan lima macam hasil belajar, tiga diantaranya bersifat kognitif, satu bersifat afektif, dan satu lagi bersifat psikomotorik. Secara sederhana, hasil belajar murid adalah kemampuan yang diperoleh anak setelah melalui kegiatan belajar. Karena hasil belajar itu sendiri merupakan suatu proses dari seseorang yang berusaha untuk memperoleh suatu bentuk perubahan perilaku yang relatif menetap.

Menurut Gestalt dalam Susanto (2013:12) belajar merupakan suatu proses perkembangan artinya, bahwa secara kodrati jiwa raga anak mengalami perkembangan. Berdasarkan teori ini hasil belajar murid dipengaruhi oleh dua hal, murid itu sendiri dan lingkungannya. Pertama, siswa : dalam arti kemampuan berpikir atau tingkah laku intelektual, motivasi, minat, kesepian siswa, serta aktivitas belajar siswa. Kedua, lingkungannya: yaitu sarana dan prasarana, kompetensi guru, sumber-sumber belajar, metode serta dukungan lingkungan keluarga.

\section{Metode Praktikum}

Metode praktikum merupakan suatu cara penyajian bahwa pelajaran dan murid melakukan percobaan dengan mengalami untuk membuktikan sendiri sesuatu pertanyaan atau hipotesis yang dipelajari dan sebagai salah satu mengajar dimana murid melakukan suatu percobaan tentang suatu hal, mengamati prosesnya serta melakukan hasil suatu percobaan kemudian hasil pengamatan itu disampaikan di kelas dan dievaluasikan guru.

Menurut Djamarah dan Zain (2002:95) memberi pengertian bahwa metode praktikum adalah proses pembelajaran dimana peserta didik melakukan dan mengalami sendiri, mengikuti proses, mengamati obyek, menganalisis, membuktikan 
dan menarik kesimpulan suatu obyek, keadaan dan proses dari materi yang dipelajari tentang struktur bagian tumbuhan.

Pada dasarnya konsep metode praktikum yaitu menyajikan pelajaran dimana peserta didik melakukan percobaan dengan mengalami dan membuktikan sendiri sesuatu yang dipelajari. Atau dengan kata lain siswa di ajak langsung untuk mengamati dan melihat secara langsung sesuai dengan materi yang akan diajarkan. Konsep metode praktikum dalam proses belajar mengajar di khususkan peserta didik diberi kesempatan mengalami sendiri atau melakukan sendiri, mengikuti suatu proses, mengamati suatu objek, menganalisis, membuktikan dan menarik kesimpulan sendiri mengenai suatu objek, keadaan atau proses sesuatu.

Menurut Djajadisastra (1982:11, dalam Yunita 2013:25) ada tiga langkah utama yang perlu dilakukan, yaitu langkah persiapan, langkah pelaksanaan dan tindak lanjut metode praktikum.

\section{METODE PENELITIAN}

Penelitian ini merupakan penelitian eksperimen yaitu metode penelitian yang digunakan untuk mencari pengaruh perlakuan tertentu terhadap yang lain dalam kondisi yang terkendalikan. Desain pada penelitian ini adalah One-Group Pretestposttest Design.

Populasi penelitian ini adalah seluruh jumlah siswa kelas IV di SDN No.166 InpresBontorita kecamatan Polong Bangkeng Utara Kabupaten Takalar yang berjumlah 20 orang. sampel penelitian yang dimaksud sebanyak 20 orang yang terdiri dari 8 orang laki-laki dan 12 orang perempuan. Instrumen dalam penelitian ini menggunakan tes hasil belajar (pretest dan posttest) sebelum dan setelah diterapkan metode praktikum. Untuk mengetahui data yang diperoleh dari hasil penelitian akan digunakan Teknik Analisis Statistik Deskriptif dan Teknik Statistik Inferensial.

\section{HASIL PENELITIAN DAN PEMBAHASAN}

Hasil penelitian ini adalah jawaban dari rumusan masalah yang telah ditetapkan sebelumnya. Dimana untuk menjawab rumusan masalah digunakan analisis statistik deskriptif dan analisis statistik inferensial sekaligus menjawab hipotesis yang telah 
ditetapkan. Jadi hasil penelitian yang didapatkan setelah penelitian dirincikan sebagai berikut:

1). Data Hasil Pretest

Skor hasil belajar IPA siswa sebelum diberikan perlakuan atau sebelum diterapkan metode praktikum (pretest) pada siswa kelas IV SDN No. 166 Inpres Bontorita Kabupaten Takalar disajikan secara lengkap pada lampiran d.

Selanjutnya berdasarkan hasil analisis deskriptif terhadap skor hasil belajar IPA siswa sebelum diberikan perlakuan (pretest) ditunjukkan seperti pada tabel 1 berikut:

Tabel 1 Statistik Skor Hasil Belajar IPA Siswa Sebelum Diberikan Perlakuan (Pretest)

\begin{tabular}{|c|c|}
\hline Statistik & Nilai Statistik \\
\hline Subjek & 20 \\
Skor Ideal & 100 \\
Skor Maksimum & 100 \\
Skor Minimum & 40 \\
Rentang Skor & 60 \\
Skor Rata-rata & 57,00 \\
Standar Deviasi & 18,382 \\
Variansi & 337,895 \\
\hline
\end{tabular}

Apabila skor hasil belajar IPA siswa dikelompokkan kedalam lima kelas interval skor, maka diperoleh distribusi dan frekuensi skor hasil belajar IPA sebelum diberi perlakuan seperti ditunjukkan pada tabel 2 berikut:

Tabel 2 Distribusi Frekuensi dan Persentase Skor Hasil Belajar IPA Siswa Sebelum Diberikan Perlakuan (Pretest)

\begin{tabular}{|c|l|c|c|}
\hline Skor & Kategori & Frekuensi & $\mathbf{\%}$ \\
\hline $0-54$ & Sangat Rendah & 10 & 50,0 \\
\hline $55-64$ & Rendah & 2 & 10,0 \\
\hline $65-79$ & Sedang & 5 & 25,0 \\
\hline $80-89$ & Tinggi & 2 & 10,0 \\
\hline $90-100$ & Sangat Tinggi & 1 & 5,0 \\
\hline
\end{tabular}




\begin{tabular}{|c|c|c|}
\hline Jumlah & 20 & 100,0 \\
\hline
\end{tabular}

Berdasarkan tabel 1 dan tabel 2 menunjukkan bahwa skor rata-rata hasil belajar IPA siswa pada pembelajaran sebelum diberikan perlakuan (pretest) adalah sebesar 57,00. Skor tertinggi yang dicapai siswa adalah 100,00 dan skor terendah 40,00, dengan standar deviasi sebesar 18,382 dari skor ideal 100 berada pada kategori "rendah". Hal ini berarti pada umumnya siswa yang menjadi unit penelitian skor pelajaran IPAnya tergolong rendah. Selanjutnya untuk melihat persentase ketuntasan belajar IPA siswa sebelum diberi perlakuan (pretest) dapat dilihat pada tabel 4.3 berikut:

Tabel 3 Deskripsi Ketuntasan Belajar IPA Siswa Sebelum Diberikan Perlakuan (Pretest)

\begin{tabular}{|c|c|c|c|}
\hline Interval Skor & Kategori & Frekuensi & $\begin{array}{c}\text { Persentase } \\
(\%)\end{array}$ \\
\hline $0 \leq \times<70$ & Tidak Tuntas & 12 & 60,00 \\
\hline $70 \leq x \leq 100$ & Tuntas & 8 & 40,00 \\
\hline \multicolumn{2}{|c|}{ Jumlah } & 20 & 100 \\
\hline
\end{tabular}

Sumber: SDN No. 166 Inpres Bontorita Kabupaten Takalar

Berdasarkan tabel 3 digambarkan bahwa kriteria seorang siswa dikatakan tuntas belajar apabila memperoleh skor paling rendah 70. Dari tabel tersebut terlihat bahwa jumlah siswa yang tidak memenuhi kriteria ketuntasan individu adalah sebanyak 12 orang atau 60,00\%, sedangkan 8 orang atau 40,00\% telah memenuhi kriteria ketuntasan belajar dari jumlah keseluruhan siswa. Berdasarkan deskripsi diatas dapat ditarik kesimpulan bahwa hasil belajar IPA siswa kelas IV SDN No. 166 Inpres Bontorita Kabupaten Takalar sebelum diterapkan metode praktikum masih banyak siswa yang tidak mencapai tingkat ketuntasan belajar.

2). Data Hasil Posttest

Skor hasil belajar IPA siswa setelah diberikan perlakuan atau setelah diterapkan Metode praktikum pada siswa kelas IV SDN No. 166 Inpres Bontorita Kabupaten Takalar disajikan secara lengkap pada lampiran d.

Selanjutnya berdasarkan hasil analisis deskriptif terhadap skor hasil belajar IPA siswa setelah diberikan perlakuan (posttest) ditunjukkan seperti pada tabel 4 berikut: 
Tabel 4 Statistik Skor Hasil Belajar IPA Siswa Setelah Diberikan Perlakuan (Posstest)

\begin{tabular}{|c|c|}
\hline Statistik & Nilai Statistik \\
\hline Subjek & 20 \\
Skor Ideal & 100 \\
Skor Maksimum & 100 \\
Skor Minimum & 70 \\
Rentang Skor & 30 \\
Skor Rata-rata & 90,00 \\
Standar deviasi & 10,260 \\
Variansi & 105,263 \\
\hline
\end{tabular}

Sumber: Data Olah Lampiran D (Posttest)

Selanjutnya jika skor hasil belajar IPA siswa dikelompokkan kedalam lima kategori (interval kelas), maka diperoleh distribusi frekuensi dengan persentase seperti yang ditunjukkan pada tabel 5 berikut:

Tabel 5 Distribusi Frekuensi dan Persentase Skor Hasil Belajar IPA Siswa Setelah Diberikan Perlakuan (Posttest)

\begin{tabular}{|c|l|c|c|}
\hline Skor & \multicolumn{1}{|c|}{ Kategori } & Frekuensi & \% \\
\hline $0-54$ & Sangat Rendah & 0 & 0 \\
\hline $55-64$ & Rendah & 0 & 0 \\
\hline $65-79$ & Sedang & 1 & 5,0 \\
\hline $80-89$ & Tinggi & 7 & 35,0 \\
\hline $90-100$ & Sangat Tinggi & 12 & 60,0 \\
\hline \multicolumn{2}{|r|}{ Jumlah } & 20 & 100,0 \\
\hline
\end{tabular}

Berdasarkan tabel 4 dan tabel 5 menunjukkan bahwa skor rata-rata hasil belajar IPA siswa setelah diberikan perlakuan (posttest) adalah sebesar 90,00. Skor tertinggi yang dicapai siswa adalah 100 dan skor terendah 70,00, dengan standar deviasi sebesar 10,260 dari skor ideal 100 berada pada kategori "sangat tinggi". Hal ini berarti pada umumnya siswa yang menjadi unit penelitian skor IPAnya tergolong sangat tinggi. 
Berdasarkan tabel 4.6 digambarkan bahwa kriteria seorang siswa dikatakan tuntas belajar apabila memperoleh skor paling rendah 70. Dari tabel tersebut terlihat bahwa jumlah siswa yang tidak memenuhi kriteria ketuntasan klasikal adalah sebanyak 0 orang atau $00,00 \%$ dari jumlah keseluruhan siswa, sedangkan siswa yang telah memenuhi kriteria ketuntasan klasikal adalah sebanyak 20 orang atau 100,0\% dari jumlah keseluruhan siswa. Berdasarkan deskripsi diatas dapat ditarik kesimpulan bahwa hasil belajar IPA siswa kelas IV SDN No. 166 Inpres Bontorita Kabupaten Takalar setelah diterapkan metode praktikum semuanya mencapai tingkat ketuntasan belajar.

3). Komparasi Tingkat Hasil Belajar IPA Siswa

Dari pembahasan diatas, apabila disajikan dalam tabel akan terlihat jelas perbedaan skor rata-rata hasil tes sebelum dilaksanakan perlakuan (pretest) dan skor rata-rata hasil tes setelah dilaksanakan perlakuan (posttest), yang ditunjukkan pada tabel 6 berikut:

Tabel 6 Distribusi Hasil Belajar IPA Siswa Pretest dan Posttest

\begin{tabular}{|c|c|c|}
\hline \multirow{2}{*}{ Statistik } & \multicolumn{2}{|c|}{ Nilai Statistik } \\
\cline { 2 - 3 } & Pretest & Posttest \\
\hline Ukuran sampel & 20 & 20 \\
Skor tertinggi & 100 & 100 \\
Skor terendah & 100 & 100 \\
Skor Ideal & 40 & 70 \\
Rentang Skor & 60 & 30 \\
Skor Rata-rata & 57,00 & 90,00 \\
Standar Deviasi & 29,29 & 10,260 \\
Variansi & 858,27 & 105,263 \\
\hline
\end{tabular}

Dari tabel 6 diatas digambarkan bahwa skor rata-rata hasil tes siswa setelah dilaksanakan metode praktikum lebih tinggi yaitu 90,00 dengan rentang skor 30 dibanding dengan sebelum dilaksanakan metode praktikum (pretest) skor rata-rata tes siswa yaitu 57,00 dengan rentang skor 60. 
Berdasarkan hasil analisis data hasil belajar IPA siswa sebelum diterapkan metode praktikum (pretest), menunjukkan bahwa terdapat 12 siswa dari jumlah keseluruhan 20 siswa atau 60,00\% siswa yang tidak mencapai ketuntasan individu (mendapat skor prestasi dibawah 70) sedangkan terdapat 8 siswa atau 40,00\% yang memenuhi kriteria ketuntasan individu dari jumlah keseluruhan siswa (mendapat skor prestasi diatas 70). Berdasarkan deskripsi tersebut dapat ditarik kesimpulan bahwa hasil belajar IPA siswa kelas IV SDN No. 166 Inpres Bontorita Kabupaten Takalar sebelum diterapkan Metode praktikum semuanya tidak mencapai tingkat ketuntasan belajar.

Berdasarkan hasil analisis data hasil belajar IPA siswa sebelum diterapkan Metode praktikum(pretest) dan setelah diterapkan Metode praktikum(posttest), terlihat jelas perbedaan skor rata-rata hasil tes sebelum dilaksanakan perlakuan (pretest) dan skor rata-rata hasil tes setelah dilaksanakan perlakuan (posttest) yakni skor rata-rata hasil tes siswa setelah dilaksanakan Metode praktikum (posttest) lebih tinggi yaitu 90,00 dibanding dengan sebelum dilaksanakan metode praktikum (pretest) yaitu 57,00. Berdasarkan deskripsi tersebut dapat ditarik kesimpulan bahwa Metode praktikum berpengaruh terhadap hasil belajar IPA pada siswa kelas IV SDN No. 166 Inpres Bontorita Kabupaten Takalar.

Berdasarkan hasil analisis statistik inferensial dengan menggunakan uji-t diketahui bahwa terdapat perbedaan hasil belajar yang signifikan, perbedaan antara hasil pretest dan posttest signifikan. Hal ini terlihat dimana $t_{\text {hitung }}>t_{\text {tabel }}=7,183>3,88$ sehingga disimpulkan bahwa $\mathrm{H}_{0}$ ditolak dan $\mathrm{H}_{1}$ diterima, ini berarti bahwa hipotesis dalam penelitian ini diterima yakni Ada pengaruh metode praktikum terhadap hasil belajar IPA konsep struktur bagian tumbuhan pada murid kelas IV SDN No. 166 Inpres Bontorita Kecamatan Polongbangkeng Utara Kabupaten Takalar.

\section{SIMPULAN DAN SARAN}

Berdasarkan hasil penelitian dan pembahasan yang telah dikemukakan pada Bab IV, maka dapat ditarik beberapa simpulan yang merupakan jawaban dari masalah penelitian adalah: (1) Hasil belajar IPA siswa kelas IV SDN No. 166 Inpres Bontorita kabupaten Takalar, ditinjau dari skor rata-rata hasil belajar IPA siswa setelah diberikan perlakuan sebesar 90,00 dengan standar deviasi 10,260 dari skor ideal 100 
berada pada kategori sangat tinggi. Hal ini menunjukkan bahwa hasil belajar IPA siswa tuntas berdasarkan KKM yakni 70 dan tuntas secara klasikal yakni 75\% dari siswa yang mencapai nilai $\geq 70,00$ dimana hasil ketuntasan klasikal yang diperoleh yaitu 100\%. (2) Rata-rata persentase aktivitas aktif siswa dengan menggunakan Metode praktikum selama dua kali pertemuan adalah 82,25\% lebih besar dari kriteria yang ditetapkan untuk persentase indikator aktivitas siswa yakni 75\% sedangkan rata-rata persentase data aktivitas pasif siswa adalah 58,75\%. Sehingga dapat disimpulkan bahwa aktivitas aktif siswa lebih besar dibanding aktivitas pasif siswa. Hal ini berarti bahwa aktivitas siswa dalam pembelajaran melalui Metode praktikum tergolong aktif. (3) Berdasarkan indikator pengaruh metode praktikum ditinjau dari dua aspek yakni ketuntasan hasil belajar IPA siswa dan aktivitas siswa dalam proses pembelajaran. Dua aspek diantaranya yaitu ketuntasan hasil belajar siswa dan aktivitas siswa dalam pembelajaran dan aktivitas guru dalam pembelajaran telah terpenuhi sesuai dengan kriteria yang telah ditentukan. Dengan demikian dapat disimpulkan bahwa Metode praktikum berpengaruh untuk diterapkan dalam pembelajaran IPA pada siswa kelas IV SDN No. 166 Inpres Bontorita Kabupaten Takalar.

Saran yang dapat diberikan: (1) Kepada pihak sekolah diharapkan dapat menerapkan pembelajaran IPA melalui Metode praktikum dalam proses pembelajaran untuk lebih meningkatkan hasil belajar siswa terhadap mata pelajaran IPA yang diharapkan. (2) Disarankan kepada guru yang ingin menerapkan pembelajaran melalui Metode praktikum agar mempertimbangkan materi dan kondisi siswa sehingga dapat terlaksana dengan efektif. (3) Karena penulis tidak luput dari kesalahan dan masih adanya hal-hal yang belum terkontrol dengan baik, maka disarankan untuk mengadakan penelitian yang serupa atau relevan pelaksanaannya, dengan menggunakan waktu yang lebih banyak sehingga hasil analisis yang diharapkan lebih baik. (4) Bagi para siswa untuk membiasakan diri secara aktif, bertanya, menyampaikan ide/gagasan, membaca, berani tampil di depan temantemannya, dan menemukan sendiri jawaban dari setiap permasalahan yang ditemukan dalam pembelajaran.

\section{DAFTAR PUSTAKA}

Abdullah, 1998.Ilmu Pengetahuan Alam. Jakarta : Erlangga 
Ali, Mohammad. 2009. Pendidikan Disiplin Ilmu. Jakarta : PT. Imtima

Arends, Richard. 2001. Model Pembelajaran Untuk Mengajar. Yogyakarta : Pustaka Pelajar

Arikunto, Suharsimi. 2006. Prosedur Penelitian Suatu Pendekatan Praktik. Jakarta: PT. Rineka Cipta.

Boud, D.And G. Feletti. 1997. The challenge of problem based learning. London: Kogan Page.

Darsono dkk. 2000. Belajar dan Pembelajaran. Semarang: IKIP Semarang Press Diakses pada http://www.kajian pustaka.com. ( 2 Mei 2016 pukul 20.00 WITA).

Dimyanti Mohammad. 1996. Landasan Pendidikan; Ikip Malang

Gagne, R. M. 1992. Principles of Intructional Design.4th edition. San Diego. Brace Javonovich College Publisher.

Hamalik, Oemar. 2005. Kurikulum Dan Pembelajaran. Jakarta : Bumi Aksara

Margetson, D. 1994. Current Educational Reform and the Significance of Problem-Based -Learning. Stud. Highe Educ.; 19:5-19.

Purwanto, Ngalim. 1987. Ilmu Pendidikan.Jakarta : Remadja Karya.

Slameto.2003. Belajar Dan Faktor-Faktor Yang Mempengaruhinya.Jakarta : Rineka Cipta

Slavin, Robert E. 1995.Cooperative Learning. Boston: Allyn and Bacon.

Sudjana, Nana. 1987. Dasar-Dasar Proses Belajar Mengajar. Bandung: Usaha Nasional.

Sudjana, Nana 1989. Penilaian Hasil Proses Belajar Mengajar.Bandung : Sinar Baru Alsegindo

Sudjana, N. 2004.Belajar Dan Faktor-Faktor Yang Mempengaruhinya. Bandung : Sinar Baru Algesindo

Sugiyono. 2013. Metode Penelitian Pendidikan: Pendekatan Kuantitatif, Kualitatif dan $R$ $\& D$. Bandung: Alfabeta.

Trianto.2009. Mendesain Model Pembelajaran Inovatif Progresif.Jakarta : Kencana 